\title{
Chemical Route Manufactured ZnO Nanoparticles And Their Biological Accumulation
}

\section{Bouloudenine ( $\nabla$ m.bouloudenine@univ-soukahras.dz)}

Mohamed-Cherif Messaadia University https://orcid.org/0000-0002-7823-4208

\section{H. Laala-Bouali}

University Badji Mokhtar - Annaba

\section{K. Djeddou}

University Badji Mokhtar - Annaba

\section{Bououdina}

University of Bahrain

\section{N. Grara}

Badji-Mokhtar University

\section{Research Article}

Keywords: ZnO NPs, Co-precipitation, XRD, Raman, PL spectroscopy, Helix aspersa, Hepatopancreas, Histological study, Toxicity.

Posted Date: December 20th, 2021

DOI: https://doi.org/10.21203/rs.3.rs-1148231/v1

License: (c) (i) This work is licensed under a Creative Commons Attribution 4.0 International License. Read Full License

Version of Record: A version of this preprint was published at Journal of Inorganic and Organometallic Polymers and Materials on February 4th, 2022. See the published version at https://doi.org/10.1007/s10904-022-02240-0. 


\section{Chemical Route Manufactured ZnO Nanoparticles and their Biological Accumulation}

M. Bouloudenine ${ }^{1,2}$, H. Laala-Bouali ${ }^{3}$, K. Djeddou ${ }^{3}$, M. Bououdina ${ }^{4}$, N. Grara ${ }^{5,6}$

Corresponding author email: m.bouloudenine@univ-soukahras.dz

${ }^{1}$ Mohamed-Cherif Messaadia University - Souk Ahras, 41000, Algeria.

${ }^{2}$ LPR, Laboratory, University Badji Mokhtar - Annaba, BP 12, 23000 Algeria.

${ }^{3}$ LEREC Laboratory, University Badji Mokhtar - Annaba, BP 12, 23000, Algeria.

${ }^{4}$ Department of Physics, College of Science, University of Bahrain, PO Box 32038, Kingdom of Bahrain

${ }^{5}$ Cellular Toxicology Laboratory, Department of Biology, Faculty of Sciences, Badji-Mokhtar University, Annaba, P.O. Box 12, 23000, Algeria.

${ }^{6}$ Département de Biologie, Faculté des Sciences de la Nature et de la Vie et des Sciences de la Terre et de l'Univers, Université 8 Mai 1945, Guelma, PB 401, 24000, Algérie. 


\begin{abstract}
$\mathrm{ZnO}$ nanocrystalline powder was successfully synthesized via coprecipitation method coupled with high annealing treatment. X-ray diffraction analysis revealed that the NPs have a pure hexagonal wurtzite structure with a mean crystallite size of approximately $59 \mathrm{~nm}$. FESEM observations along with EDS analysis indicated the formation of fine particles in the nanoscale regime, with hexagonal shape and high purity. Both Raman and photoluminescence characterizations confirmed the high crystalline and the optical quality of the synthesized $\mathrm{ZnO}$ NPs. The assessment of the impact of $\mathrm{ZnO}$-based nanoparticles and their effects on body and bioaccumulative bioindicators of pollution, Helix aspersa snails was performed in order to preserve the safe development of nanotechnology.
\end{abstract}

Keywords: ZnO NPs; Co-precipitation; XRD; Raman; PL spectroscopy; Helix aspersa; Hepatopancreas; Histological study; Toxicity. 


\section{Introduction}

During the last few decades, zinc oxide $(\mathrm{ZnO})$ has regained much more interest in material science because of its large variety of nanostructures and the wide diversity of potential applications [1] [1]. $\mathrm{ZnO}$ has a wide band gap of about $3.3 \mathrm{eV}$ and large exciton binding energy of $60 \mathrm{meV}$ at room temperature, much higher than that of GaN, $21 \mathrm{meV}$ [2]. This makes it suitable for room temperature, UV lasing and short wavelength optoelectronic devices [3, 4]. Besides, its large transmittance (80-90\%) along the visible range [5] has promoted its frequent use in solar cells, transparent thin film transistors, ultraviolet (UV) photo-detectors, light emitting diodes (LEDs) and piezo-electric devices [2, 6-8]. Furthermore, $\mathrm{ZnO}$ is used as a host matrix for transition metals impurities to obtain diluted magnetic semiconductors $[9,10]$ and is also becoming very promising for gas sensing application [11]. It has been reported that $\mathrm{ZnO}$ powders at the nanoscale level ]possessed biomedical field applications such as antibacterial agent [12].

Most of the modern techniques of crystal growth make it possible to grow large size $\mathrm{ZnO}$ crystals and wafers with enhanced properties [13]. However, there is a growing interest in the preparation of a variety of $\mathrm{ZnO}$ nanoparticles (NPs) with various shapes and sizes using different methods, which show unique and novel properties [14-22] But most of these processes require rigorous experimental conditions and involved many complicated steps. However, chemical synthesis of $\mathrm{ZnO}$ is relatively simple, repeatable and cost effective. It does not require, indeed, a costly setup of equipment [23-29]. The above advantages allow polycrystalline or nanocrystalline $\mathrm{ZnO}$ to become much more attractive and very promising. 
Compared with other synthesis techniques of powders, chemical coprecipitation method, when coupled with relatively high annealing treatment, offers several advantages such as high purity, excellent control of chemical uniformity and stoichiometry of powder elements [30], simplicity in manufacturing, reproducibility and more importantly, the dopant elements could be substituted easily within $\mathrm{ZnO}$ crystal lattice under non-equilibrium conditions.

On the one hand, nanoparticles, due to their small size occupy a significant place in innovative applications in modern technology, while on the other hand; the small size of NPs may lead to their accumulation within the body leading to health hazards in living cells and human beings.

Understanding the toxic effects of nanoparticles on the environment is the biggest obstacle to the safe development of nanotechnology [31]. Recent researches have been directed towards the potential toxicity of $\mathrm{ZnO}$ as well as other metal oxide nanoparticles and nanomaterials in general. $\mathrm{Xu}$ et al. have studied the physicochemical factors that govern toxic effects of nanomaterials (NMs) for the safe design and synthesis of NMs. They concluded that the cytotoxicity on living cells associated with $\mathrm{ZnO}$ NPs is not a function of the $\mathrm{Zn}$ concentration, and suggested that other factors play an important role in the toxic effect of $\mathrm{ZnO}$ NPs [32]. The interaction of the most studied metal oxides, namely $\mathrm{TiO}_{2}, \mathrm{ZnO}$ and $\mathrm{Fe}_{3} \mathrm{O}_{4}$ nanoparticles with aquatic species has been investigated by Hazeeme et al. [33, 34]. However, no study has been performed on the assessment of interaction mechanisms of zinc oxide nanoparticles ( $\mathrm{ZnO} \mathrm{NPs}$ ) on the terrestrial gastropods Helix aspersa snails which are recognized as relevant environmental indicators by their ability to accumulate the most frequent trace elements such as $\mathrm{Cd}, \mathrm{Pb}$ and $\mathrm{Zn}$. 
and their capacities to accumulate different classes of chemicals in their tissues, mainly, the hepatopancreas [35-37].

In this study, we adopted chemical co-precipitation route using oxalic acid and $\mathrm{Zn}\left(\mathrm{CH}_{3} \mathrm{COOH}\right)$ as precursor, followed by subsequent annealing at a relatively high temperature $(1073 \mathrm{~K})$ but for a short period of time (15 minutes only) in order to produce pure $\mathrm{ZnO}$ NPs. This simple method uses less expensive equipment and easy to handle compared to other technique, hence considered as low-cost technique and more promising in bulk production.

Structure, microstructure and optical properties were studied and the obtained results were discussed. The possible use of cellular alterations on the gastropods' hepatopancreas as bioindicator for the exposure to ZnO NPs has been also investigated in this assessment.

\section{Experimental Part}

\subsection{Preparation of $\mathrm{ZnO}$ Nanopowder}

The precursor was prepared from the decomposition of an oxalate precursor in which $\mathrm{O}$ and $\mathrm{Zn}$ ions are already intimately mixed. The oxalate precursor was obtained by coprecipitation of $100 \mathrm{ml}$ of a $0.4 \mathrm{~mol} / \mathrm{l}$ aqueous solution of zinc acetates " $\mathrm{Zn}\left(\mathrm{CH}_{3} \mathrm{COO}\right)_{2} .2 \mathrm{H}_{2} \mathrm{O}$ " with the same volume of a $0.4 \mathrm{~mol} / 1$ solution of oxalic acid " $\mathrm{C}_{2} \mathrm{H}_{2} \mathrm{O}_{4}$ "at room temperature. After about 72 hours of decantation, the white precipitate was thoroughly washed with distilled water and dried in air at $373 \mathrm{~K}$ for 2 hours. The as-obtained white powder was then heated at $1073 \mathrm{~K}$ for $15 \mathrm{~min}$ in air, its colour turned into light-yellow.

\subsection{Biological Material}

The used biological material consists in a terrestrial snail Helix aspersa which was collected from Souk Ahras city in the east of Algeria, exactly in the 
region of Khmissa, Which is naturally considered as a virgin area. The snails, with an average weight of $6 \mathrm{~g}$ were cultivated in the optimal environmental conditions following the photoperiods of $18 \mathrm{~h}$ light/day, temperature of $20^{\circ} \mathrm{C}$, humidity of 80 to $95 \%$ and fed on food wheat flour. After that, they were kept in transparent polystyrene boxes with perforated lid. Power is supplied in petri dishes regularly every three days.

\subsection{Bio-Essay Measurements}

The treatment of snails was performed by adding different concentrations of nanoparticles in the diet. Several concentrations $(0,100,200,500,1000,2000,5000$, $10000 \mu \mathrm{g} / \mathrm{g}$ ) were selected. The sails were divided into six boxes including 13 adults in each one. The bio-essay was performed during 28 days. After the bio-essay was accomplished, the infected snails were weighed, placed quickly into the freezer for $48 \mathrm{~h}$ in order to empty their gut and then dissected, to get their hepatopancreas.

\section{Characterization}

Powder X-ray diffraction pattern has been recorded using Rigaku Ultima IV high resolution $\mathrm{X}$-ray diffractometer equipped with $\mathrm{Cu}-\mathrm{K} \alpha$ radiation $(\lambda=$ $0.15418 \mathrm{~nm}$ ). Rietveld refinements were carried out using PDXL program. The measurements have been performed at room temperature. Microstructure was characterized using a field emission scanning electron microscope (FESEM) Lyra 3 Tescan in a secondary electron (SE) and back scattering electron (BSE) modes at an accelerating voltage up to $30 \mathrm{kV}$. Energy dispersive X-ray (EDX) spectroscopy was used to determine the elemental chemical composition. Raman spectrum was recorded on an iHR320 Yvon Horiba spectrophotometer using laser excitation wavelength of $532 \mathrm{~nm}$ with a power of $300 \mathrm{~mW}$ operated at $62 \%$ capacity. The room 
temperature photoluminescence (PL) spectrum was recorded by a FluoroLog®-3 spectrofluorometer with 450W Xenon lamp source equipped by a double excitation grating monochromators with a standard R928 PMT detector that covers the full range from UV to near-IR. The excitation wavelengths were 300 and $325 \mathrm{~nm}$.

\section{Results and Discussion}

XRD pattern of ZnO NPs prepared by co-precipitation method coupled with annealing treatment is shown in Figure 1a. All the observed diffraction peaks were indexed using the hexagonal wurtzite type structure in accordance to JCPDS Card No. 36- 1451. No additional peaks from un-reacted precursors, by-products or formed impurities, can be detected. Hence, it confirms the formation of pure single $\mathrm{ZnO}$ crystalline phase.

Qualitative and quantitative phase analyses were carried out using the Rietveld method, where both structural (lattice parameters) and microstructural parameters (crystallite size and microstrain: the shape of peaks is defined by a pseudo- voight function representing a linear combination of Gaussian for microstrain and Lorentzianfor crystallite size) were refined. Figure 1b shows a typical refined XRD pattern. The R-factors fit the parameters (weighted profile Rfactor $(\mathrm{Rwp})=10.30 \%$, un-weighted profile $\mathrm{R}$-factor $(\mathrm{Rp})=6.56 \%$, expected -factor $(\mathrm{Re})=6.11 \%$, goodness of fir $(\mathrm{S})=1.68$ and $\chi^{2}=2.8$, where $\mathrm{S}=\mathrm{Rwp} / \mathrm{Re}$ and $\chi^{2}=$ $S^{2}$ ) indicate the good quality of the refinements and confirming the formation of single $\mathrm{ZnO}$ phase. The refined lattice parameters $\mathrm{a}=3.2510(2)$ and $\mathrm{c}=5.2076(3)$ $\AA$, are in a good agreement with some values reported in the literature [38]. The refined microstructural parameters values, such as crystallite size of $59 \mathrm{~nm}$ and 
microstrain $0.041 \%$, indicate the formation of nanocrystalline phase with less structural defects.

Morphological observations of the as-synthesized ZnO NPs were confirmed by FESEM as shown in Figure 2. The images show an hexagonal-like shaped particles with non-homogenous size distribution. It can be observed that the particles size is in the nanometer range with a clustering of NPs into larger aggregates (high tendency of agglomeration).

Figure 3a showing a typical EDX spectrum clearly rveals the presence of $\mathrm{Zn}$ and $\mathrm{O}$ elements only. Thus, it indicates the high purity of as-prepared $\mathrm{ZnO}$ nanopowder in agreement with XRD results. The elemental chemical composition as-determined by EDX using area analysis in 3 different regions (Figure $\mathbf{3 b}$ ) gives the following values (see Table 1): Zn:75 $\pm 1 \mathrm{wt} . \%$ and $0: 25 \pm 1 \mathrm{wt} . \%$, which are close to the nominal composition of $\mathrm{ZnO}$.

Raman spectral analysis for as-synthesized $\mathrm{ZnO}$ nanopowder at room temperature is shown in Figure $\mathbf{4}$ and the obtained results are reported in Table 2. Würtzite hexagonal $\mathrm{ZnO}$ belongs to the space group symmetry (P63mc) which is characterized by the following Raman modes:

$$
\Gamma=2\left(A_{1}+B_{1}+E_{1}+E_{2}\right)
$$

Amid these modes, there are acoustic modes (2) and optical modes (3):

$$
\begin{gathered}
\Gamma_{\text {acous }}=\mathrm{A}_{1}+\mathrm{E}_{1} \\
\Gamma_{\mathrm{opt}}=\mathrm{A}_{1}+2 \mathrm{~B}_{1}+\mathrm{E}_{1}+2 \mathrm{E}_{2}
\end{gathered}
$$

$2 \mathrm{~B}_{1}$ are the silent phonons [39] while the other modes are the Raman active phonons [40]. $\mathrm{E}_{2}^{\text {low }}$ and $\mathrm{E}_{2}^{\text {high }}$ are the non-polar modes, while $\mathrm{A}_{1}$ and $\mathrm{E}_{1}$ are polar and can be divided into transverse optical (TO) and longitudinal optical (LO) mode 
components « $\mathrm{A}_{1}^{\mathrm{LO}}, \mathrm{A}_{1}^{\mathrm{TO}}, \mathrm{E}_{1}^{\mathrm{LO}}, \mathrm{E}_{1}^{\mathrm{TO}} \gg$. All these modes are presented in the recorded spectrum of $\mathrm{ZnO}$ NPs, which confirm the pure hexagonal würtzite $\mathrm{ZnO}$ structure and the high crystalline order of as-synthesized nanopowder. The two first order modes are observed at 98 (which is not indicated in Fig.4-B) and $429 \mathrm{~cm}^{-1}$ corresponding respectively to $\mathrm{E}_{2}^{\text {low }}$ and $\mathrm{E}_{2}^{\text {high }}$. Two additional weak second order modes located at 322 and $531 \mathrm{~cm}^{-1}$, are attributed to $E_{2}^{\text {high }}-E_{2}^{\text {low }}$ and $E_{2}^{\text {high }}+E_{2}^{\text {low }}$, respectively. The bands which were observed around 397 and $575 \mathrm{~cm}^{-1}$ are attributed to the $\mathrm{E}_{1}^{\mathrm{TO}}$ and $\mathrm{A}_{1}^{\mathrm{LO}}$, respectively. All these recorded bands are reported in Table 2. Various bands linked to different multi-phonon process are situated around 200,322 and $651 \mathrm{~cm}^{-1}$. The second order Raman band of $\mathrm{ZnO}$ nanopowder is also verified in the range $900-1200 \mathrm{~cm}^{-1}$ [41], which is presented by several bands in Fig. 4-C. Again, the high intensity and the sharp form of Raman mode $\mathrm{E}_{2}^{\text {high }}$ verify the good crystalline quality of the synthesized $\mathrm{ZnO}$ NPs.

The relationship between structure and optical properties is investigated by photoluminescence (PL) spectroscopy. In fact, oxygen vacancies and intrinsic defects affect significantly the optical properties of oxide nanostructures. The PL spectrum of as-synthesized $\mathrm{ZnO}$ nanopowder, which is characterized by a typical Gaussian multiple peaks, is shown in Figure 5. The bands of $B_{1}, B_{2}, B_{3}$ and $B_{4}$ have the peak center located at $465.28,495.22,530.68$ and $544.11 \mathrm{~nm}$ respectively. The values of peak position, intensity and the FWHM are summarized in Table 3. The Blue emission is observed in $B_{1}$ at around $465 \mathrm{~nm}$ and in $B_{2}$ at around $495 \mathrm{~nm}$, while the green emission occurs in $\mathrm{B}_{3}$ and $\mathrm{B}_{4}$ at $530-544 \mathrm{~nm}$. The origin of green band is generally ascribed to oxygen vacancies and intrinsic defects [42, 43]. Vanheusden et al. attributed this green emission to the transition between photo-excited holes and singly ionized oxygen vacancies [44]. The blue emission band around $465 \mathrm{~nm}$ 
may be attributed to the direct recombination of conduction electron in the $\mathrm{Zn}_{3 \mathrm{~d}}$ and a hole in the $\mathrm{O}_{2 \mathrm{p}}$ valence band [45], while the emission at around $495 \mathrm{~nm}$ can be ascribed to the transition of oxygen anti-site vacancy defect $\mathrm{O}_{\mathrm{Zn}}$ [Error! Bookmark not defined.-47].

The toxicity of ZnO NPs on physiological parameters of Helix aspersa is determined following several concentrations in the range 100-10000 $\mu \mathrm{g} / \mathrm{g}$. The initial results show that the presence of $\mathrm{ZnO}$ NPs caused an inhibition dosedependence and the estimated concentrations that inhibit 50, 75, 90 and $100 \%$ of growth are calculated for 28 days and reported in Table 4. Moreover, the highest concentration that has no effect (NOEC) is $2000 \mu \mathrm{g} / \mathrm{g}$ and the lowest concentration that had an effect (LOEC) is $5000 \mu \mathrm{g} / \mathrm{g}$.

A histological examination of the hepatopancreas of the control group is presented in Figure 6a. It indicates that the tissue of the digestive gland essentially consists of numerous associations of digestive tubules which have several shapes and sizes and which are separated by inter tubular space, composed of hemolymphatic vessels and hemocytes. A simple epithelium of several cellular types lines the lumen of the tubules. These cells have various morphologies, but they have three main cellular types: digestive, calcium and excretory cells [48]. Tubules are maintained coherently by the intertubular connective tissue. Digestive cells constitute the major cellular component of the digestive gland tubule epithelium, and they are relatively polymorphic according to the stage of digestion [49].

After 28 days of treatment, the histological examination of the infected snail's hepatopancreas showed changes as response to all the treatments. In the concentration, $100 \mu \mathrm{g} / \mathrm{g}$ of $\mathrm{ZnO}$ NPs (Figure $7 \mathrm{~b}$ ), a remarkable increase in the number of excretory vacuoles, a partial degeneration of some digestive cells and more and larger intertubular connective tissues were observed. So, in the concentrations, 500-2000 $\mu \mathrm{g} / \mathrm{g}$ (Figure 7c, 7d, 7e and 7f), the same changes were observed, and they were accompanied by dose-dependent alterations in apical cell border, the discharge of rubbles into the lumen, and collapses in the basement 
membrane of the digestive tubule. The number of collapses increased in a dosedependent manner. At much higher doses of 5000 and $10000 \mu \mathrm{g} / \mathrm{g}$ of $\mathrm{ZnO}$, similar behavior was observed, followed by a strong degeneration of the connective tissues, digestive tubules and their membranes.

\section{Conclusion}

$\mathrm{ZnO}$ NPs were successfully synthesized by chemical co-precipitation method, coupled with annealing for a very short time. X-ray diffraction and Raman analyses confirm the formation of pure nanocrystalline hexagonal würtzite structure with a crystallite size close to $59 \mathrm{~nm}$. Hexagonally-shaped $\mathrm{ZnO}$ particles in the nanosclae regime were observed by FESEM analysis. The high crystalline and the optical quality of $\mathrm{ZnO}$ nanopowder were verified by Raman and PL measurements. PL spectra of ZnO NPs showed a visible wide-ranging PL emission in blue and green bands, which were attributed to the structural defects.

The toxicity of $\mathrm{ZnO}$ is determined using snail Helix aspersa through bioassay measurements. The snails were exposed to various concentrations of $\mathrm{ZnO}$ NPs $(100-10000 \mu \mathrm{g} / \mathrm{g})$. Preliminary results show that the presence of ZnO NPs induces dose-dependent inhibition growth.

The histological study of the infected snail's hepatopancreas revealed degeneration of the digestive tubules, disintegration of the digestive cells and collapse of basement membrane in a dose-dependent manner, leading to a severe deterioration of the tissues for the highest concentrations.

The findings of the present study indicate that the terrestrial gastropod snails are useful organisms for testing the sub-lethal toxicity of NPs acting via the food, which is the main route of toxicant uptake in land animals. Then, with regards to these results, this approach can be generalized for future tests in the other NPs, and can serve for the evaluation of risks which can undergo in terrestrial ecosystems. 


\section{Acknowledgment}

The authors acknowledge for the funding support le Ministère de l'Enseignement supérieur et de la Recherche Scientifique «MESRS » of Algeria and la Direction Générale de la Recherche Scientifique et du Développement Technologique «DGRSDT » of Algeria. 


\section{Table Captions}

Table 1 Elemental chemical composition of $\mathrm{ZnO}$ nanopowder as determined by EDX.

Table 2 Mode orders of Raman peak of $\mathrm{ZnO}$ nanopowder.

Table 3 Band peak centers, bandwidths and relative intensities of Gaussian decomposed photoluminescence spectra of $\mathrm{ZnO}$ nanopowder.

Table 4 The estimated concentrations of $\mathrm{ZnO}$ NPs that inhibit 50, 75, 90 and 100\% of growth, calculated for 28 days. 


\section{Figure Captions}

Fig. 1 (A) XRD pattern of $\mathrm{ZnO}$ nanopowder; (B) Rietveld analysis refined pattern of $\mathrm{ZnO}$ nanopowder (Red line: Measured data; Blue line: Calculated data; Green line: Residual data).

Fig. 2 FESEM images of ZnO NPs, shape and size distribution of particles in the nanopowder.

Fig. 3 EDX results of ZnO nanopowder, (A) EXD spectrum and (B) SEM image of the analyzed regions of the nanopowder.

Fig. 4 Raman spectra of $\mathrm{ZnO}$ nanopowder (the Raman phonon modes are fitted with Lorentzien function).

Fig. 5 Room temperature photoluminescence spectra of $\mathrm{ZnO}$ nanopowder exited at $325 \mathrm{~nm}$. (The emission spectra are analyzed by fitting with multiple Gaussian curves).

Fig. 6 Histological sections of the hepatopancreas of snails H. aspersa in control and treated groups (after 4 weeks of treatment with $\mathrm{ZnO}$ NPs). L, Digestive tubule lumen; DC, digestive cells; CC, calcium cells; EC, excretory cells; Ict, intertubular connective tissue; eg, excretory granules; $\mathrm{BM}$, basement membrane; Bm, border in encounter of microvilli; Acb, apical cell border. (a) Control snails. (b) snails treated with $100 \mu \mathrm{g} / \mathrm{g}$ of ZnO NPs. (c) snails treated with $500 \mu \mathrm{g} / \mathrm{g}$ of ZnO NPs. (d) snails treated with $1000 \mu \mathrm{g} / \mathrm{g}$ of ZnO NPs. (e) snails treated with $1500 \mu \mathrm{g} / \mathrm{g}$ of ZnO NPs. (f) snails treated with $2000 \mu \mathrm{g} / \mathrm{g}$ of ZnO NPs. (g) snails treated with $5000 \mu \mathrm{g} / \mathrm{g}$ of ZnO NPs. (h) snails treated with $10000 \mu \mathrm{g} / \mathrm{g}$ of $\mathrm{ZnO}$ NPs. 


\section{References}

[1] K. Vanheusden, C. H. Seager, W. L. Warren, D. R. Tallant, and J. A. Voigt, Correlation between photoluminescence and oxygen vacancies in $\mathrm{ZnO}$ phosphors, Applied Physics Letters, 68 , 3, 403-405 (1996).

[2] Y. Chen, D.M. Bagnall, H.J. Koh, K.T. Park, K. Hiraga, Z. Zhu, et al., Plasma assisted molecular beam epitaxy of $\mathrm{ZnO}$ on c -plane sapphire: Growth and characterization, Journal of Applied Physics, 84, 3912-3918 (1998).

[3] S.B. Majumder, M. Jain, P.S. Dobal, R.S. Katiyar, Investigations on solution derived aluminium doped zinc oxide thin films, Material Science and Engineering B, 103, 16-25 (2003).

[4] L. Dong, Y.C. Liu, Y.H. Tong, Z.Y. Xiao, J.Y. Zhang, Y.M. Lu, et al., Preparation of $\mathrm{ZnO}$ colloids by aggregation of the nanocrystal subunits, Journal of Colloid and Interface Science, 283, 380-384 (2005).

[5] M. Sahal, B. Hartiti, B. Mari, A. Ridah, M. Mollar, Etude des propriétés physiques des couches minces de $\mathrm{ZnO}$ dopées $\mathrm{Al}$, préparées par la méthode de «sol-gel» associée au «spin coating», Afrique Science, 02, 245-254 (2006).

[6] DC. Look, Progress in $\mathrm{ZnO}$ materials and devices, Journal of Electronic Materials, 35, 6, 1299- 1305 (2006).

[7] C. Klingshirn, ZnO: From basics towards applications, Physica Status Solidi B, $244,9,3027-3073$ (2007).

[8] C. Jagadish, S. Pearton Eds., Zinc oxide bulk, thin films and nanostructures, 1st ed., Elsevier Science, USA, (2006).

[9] H. Li, Y. Qiao, J. Li, H. Fang, D. Fan, W. Wang, A sensitive and label-free photoelectrochemical aptasensor using Co-doped $\mathrm{ZnO}$ diluted magnetic semiconductor nanoparticles, Biosensors \& Bioelectronics, 77, 378-384 (2015).

[10] G. Shanmuganathan, ·and I. B. Shameem Banu, Room temperature optical and magnetic properties of $(\mathrm{Cu}, \mathrm{K})$ doped $\mathrm{ZnO}$ based diluted magnetic semiconductor thin films grown by chemical bath deposition method, Superlattices and Microstructures, 75, 879-889, (2014).

[11] J.D. Prades, F. Hernandez-Ramirez, R. Jimenez-Diaz, M. Manzanares, T. Andreu, A. Cirera, et al., The effects of electron-hole separation on the 
photoconductivity of individual metal oxide nanowires, Nanotechnology, 19,46, 465501 (2008).

[12] M. G. Nair, M. Nirmala, K. Rekha, A. Anukalian, Structural, optical, photo catalytic and antibacterial activity of $\mathrm{ZnO}$ and $\mathrm{Co}$ doped $\mathrm{ZnO}$ nanoparticles, Materials Letters, 65 (2011) 1797-1800.

[14] A. Sundaresan, R. Bhargavi, N. Rangarajan, U. Siddesh, C. N. R. Rao, Ferromagnetism as a universal feature of nanoparticles of the otherwise nonmagnetic oxides, Physical Review B, 74, 161306 (R) (2006).

[15] R. K. Thareja, A. Mitra, Random laser action in ZnO, Applied Physics B, 71, 181-184 (2000).

[16] H.D. Li, S.F. Yu, SP. Lau, E.S.P. Leong, Simultaneous formation of visible and ultraviolet random lasings in $\mathrm{ZnO}$ films, Applied Physics Letters, 89, 2, 021110- 021112 (2006) .

[17] H.C. Ong, J.Y.Dai, A.S.K. Li, G.T. Du, R.P.H. Chang, S.T.Ho, Effect of a microstructure on the formation of self-assembled laser cavities in polycrystalline ZnO, Journal of Applied Physics, 90, 1663-1665 (2001).

[18] P. Zu, Z.K. Tang, G.K.L. Wong, M. Kawasaki, A. Ohtomo, H. Koinuma, et al., Ultraviolet spontaneous and stimulated emissions from $\mathrm{ZnO}$ microcrystallite thin films at room temperature, Solid State Communications, 103,8, 459-463 (1997).

[19] G. Tobin, E. McGlynn, M.O. Henry, J.P. Mosnier, J.G. Lunney, D. O’Mahony, et al., Ultraviolet stimulated emission from bulk and polycrystalline $\mathrm{ZnO}$ thin films with varying grain sizes, Physica B Condensed Matter (340-342) 245249 (2003).

[20] A. Fouchet, W. Prellier, B.Mercey, Influence of the microstructure on the magnetism of Co-dop2led ZnO thin films, Journal of Applied Physics, 100, 013901- 013901-6 (2006).

[21] J.V.Foreman, H.O. Everitt, J. Yang, J. Liu., Influence of temperature and photoexcitation density on the quantum efficiency of defect emission in $\mathrm{ZnO}$ powders, Applied Physics Letters, 91, 011902-011902-3 (2007).

[22] Q. Xu, H. Schmidt, S. Zhou, K. Potzger, M. Helm, H. Hochmuth, et al., Room temperature ferromagnetism in $\mathrm{ZnO}$ films due to defects, Applied Physics Letters., 92, 082508-082508-3 (2008). 
[23] J. Petersen, C. Brimont, M. Gallart, O. Crégut, G. Schmerber, P. Gilliot, et al., Structural and photoluminescence properties of $\mathrm{ZnO}$ thin films prepared by sol-gel process, Journal of Applied Physics, 104, 113539-113539-5 (2008).

[24] M. Bouloudenine, N. Viart, S. Colis, A. Dinia, Bulk Zn1 - xCo xO magnetic semiconductors prepared by hydrothermal technique, Chemical. Physics Letters, 397, 73-76 (2004).

[25] M. Bouloudenine, N. Viart, S. Colis, A. Dinia, Zn1-xCoxO diluted magnetic semiconductors synthesized under hydrothermal conditions, Catalysis Today, 113, 240-244 (2006).

[26] J. Petersen, C. Brimont, M. Gallart, O. Crégut, G. Schmerber, P. Gilliot, et al., Optical properties of $\mathrm{ZnO}$ thin films prepared by sol-gel process, Microelectronics Journal, 40, 2, 239-241 (2009).

[27] B. W. Chieng ,Y. Y. Loo, Synthesis of $\mathrm{ZnO}$ nanoparticles by modified polyol method, Materials Letters, 73, 78-82 (2012).

[28] R. He, R. K. Hocking, T. Tsuzuki, Co-doped ZnO nanopowders: location of cobalt and reduction in photocatalytic activity, Materials Chemistry and Physics,132, 10351040 (2012).

[29] Amrut S. Lanje ,Satish J. Sharma , Raghumani S. Ningthoujam , J.-S. Ahn , Ramchandra B. Pode, Low temperature dielectric studies of zinc oxide $(\mathrm{ZnO})$ nanoparticles prepared by precipitation method, Advanced Powder Technology, 24, 331-335 (2013).

[30] M. Bouloudenine, N. Viart, S. Colis, J. Kortus, and A. Dinia, Antiferromagnetism in bulk $\mathrm{Zn} 1-\mathrm{xCoxO}$ magnetic semiconductors prepared by the coprecipitation technique, Applied Physics Letters, 87, 052501-052501-3 (2005).

[31] M. Pandurangan and D.H. Kim, In vitro toxicity of zinc oxide nanoparticles: a review, Journal of Nanoparticle Research, 17, 3, 1-8 (2015).

[32] M. Xu, J. Li, N. Hanagata, H. Su, H. Chen, and D. Fujita, Challenge to assess the toxic contribution of metal cation released from nanomaterials for nanotoxicology-The case of ZnO nanoparticles, Nanoscale, 5, 11 (2013).

[33] L. J. Hazeem, M. Bououdina, S. Rashdan, L. Brunet, C. Slomianny, and R. Boukherroub, Cumulative effect of zinc oxide and titanium oxide nanoparticles on growth and chlorophyll a content of Picochlorum sp, Environmental Science and Pollution Research, 5493 (2015).

[34] L. J. Hazeem, F. Abdul Waheed, S. Rashdan, M. Bououdina, L. Brunet, C. Slomianny, et al., Effect of magnetic iron oxide $\left(\mathrm{Fe}_{3} \mathrm{O}_{4}\right)$ nanoparticles on the growth and photosynthetic pigment content of Picochlorum sp, Environmental Science and Pollution Research, 22, 15, 4370-5 (2015). 
[35] K. Simkiss, and B. Watkins, Differences in Zinc Uptake Between Snails (Helix aspersa (Muller)) from Metal- and Bacteria-Polluted Sites, Functional Ecology, 5, 6, 787 (1991).

[36] F. Gimbert, M. G. Vijver, M. Coeurdassier, R. Scheifler, W.J G M. Peijnenburg, P. M. Badot, et al., How subcellular partitioning can help to understand heavy metal accumulation and elimination kinetics in snails, Environmental Toxicology and Chemistry, 27, 6, $1284-1292$ (2008).

[37] V. A. Gomot-de, and F. Pihan, Methods for toxicity assessment of contaminated soil by oral or dermal uptake in land snails: Metal bioavailability and bioaccumulation, Environmental Toxicology and Chemistry, 2, 4, 820-827 (2002).

[38] JCPDS-ICDD, PCPDFWIN 1.1, 36-1451 (1995).

[39] D. Ferrand, J. Cibert, A. Wasiela, C. Bourgognon, S. Tatarenko, G. Fishman, et al., Carrier-induced ferromagnetism in p-Zn1-xMnxTe, Physical Review B, 63, 085201 (2001).

[40] J. M. D. Coey, M. Viret, and S. Von Molnár, Mixed-valence manganites, Advances in Physics, 48, 167 - 293 (1999).

[41] R. Udayabhaskar, R.V Mangalaraja and B. Karthikeyan, Thermal annealing induced structural and optical properties of $\mathrm{Ca}$ doped $\mathrm{ZnO}$ nanoparticles, Journal of Matterials Science: Materials in Electronics, 24, 9, 3183-3188 (2013).

[42] Q. Ahsanulhaq, A. Umar, Y.B. Hahn, Growth of aligned $\mathrm{ZnO}$ nanorods and nanopencils on $\mathrm{ZnO} / \mathrm{Si}$ in aqueous solution: growth mechanism and structural and optical properties, Nanotechnology, 18, 115603-115609 (2007).

[43] Y. Sun, N.G. Ndifor-Angwafor, D.J. Riley, M.N.R.Ashfold, Synthesis and photoluminescence of ultra-thin $\mathrm{ZnO}$ nanowire/nanotube arrays formed by hydrothermal growth, Chemical Physics Letters, 431, 4, 352-357 (2006).

[44] K. Vanheusden, W.L. Warren, C.H. Seager, D.R. Tallant, J.A. Voigt, B.E. Gnade, Mechanisms behind green photoluminescence in $\mathrm{ZnO}$ phosphor powders, Journal of Applied Physics, 79, 7983-7990 (1996).

[45] T. K. Kundu, N. Karak, P. Barik and S. Saha, Optical properties of Zn nanoparticles prepared by chemical method using Poly (VinylAlcohol) (PVA) as capping agent, International Journal of Soft Computing and Engineering, 1, 19-24 (2011).

[46] P. Schroer, P. Kriiger and J. Pollmann, First-principles calculation of the electronic structure of the wurtzite semiconductors $\mathrm{ZnO}$ and $\mathrm{ZnS}$, Physical Review B, 47, 69716980 (1993).

[47] R.B. Kale, Y.J. Hsu, Y.F. Lin, and S.Y. Lu, Synthesis of stoichiometric flowerlike ZnO nanorods with hundred per cent morphological yield, Solid State Communication, 142, 302-305 (2007). 
[48] B. Zaldibar, I. Cancio, M. Soto and I. Marigomez, Changes in cell-type composition in digestive gland of slugs and its influence in biomarkers following transplantation between a relatively unpolluted and chronically metal-polluted site, Environmentam Pollution, 156, 367-379 (2008).

[49] S. Heusser, H. G. Dupuy, Synthese de la structure tissulaire à la réalisation des fonctions chez les Gastéropodes Pulmonés (I) Eléments d'histologie et de physiologie des espèces Helixaspersa et Helixpomatia, Folia chonchiliologica 10, 3 25 (2011). 
Figures
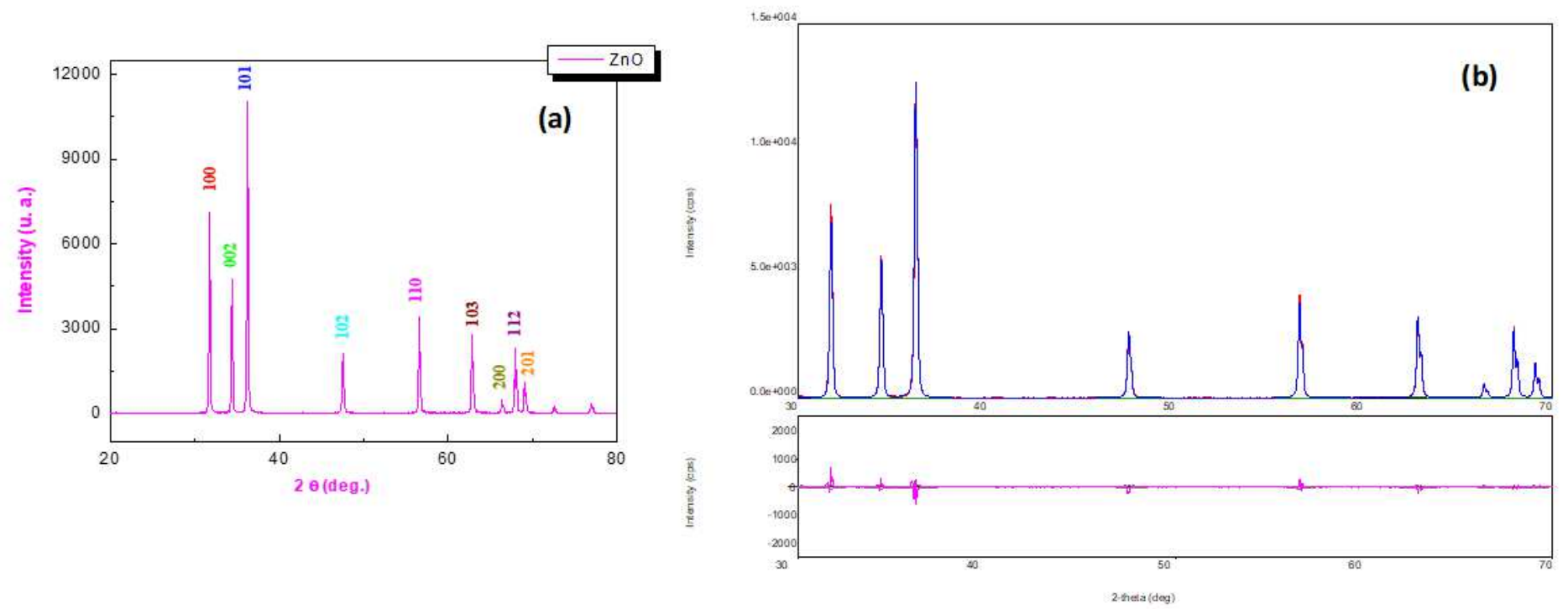

\section{Figure 1}

(A) XRD pattern of $\mathrm{ZnO}$ nanopowder; (B) Rietveld analysis refined pattern of $\mathrm{ZnO}$ nanopowder (Red line: Measured data; Blue line: Calculated data; Green line: Residual data). 

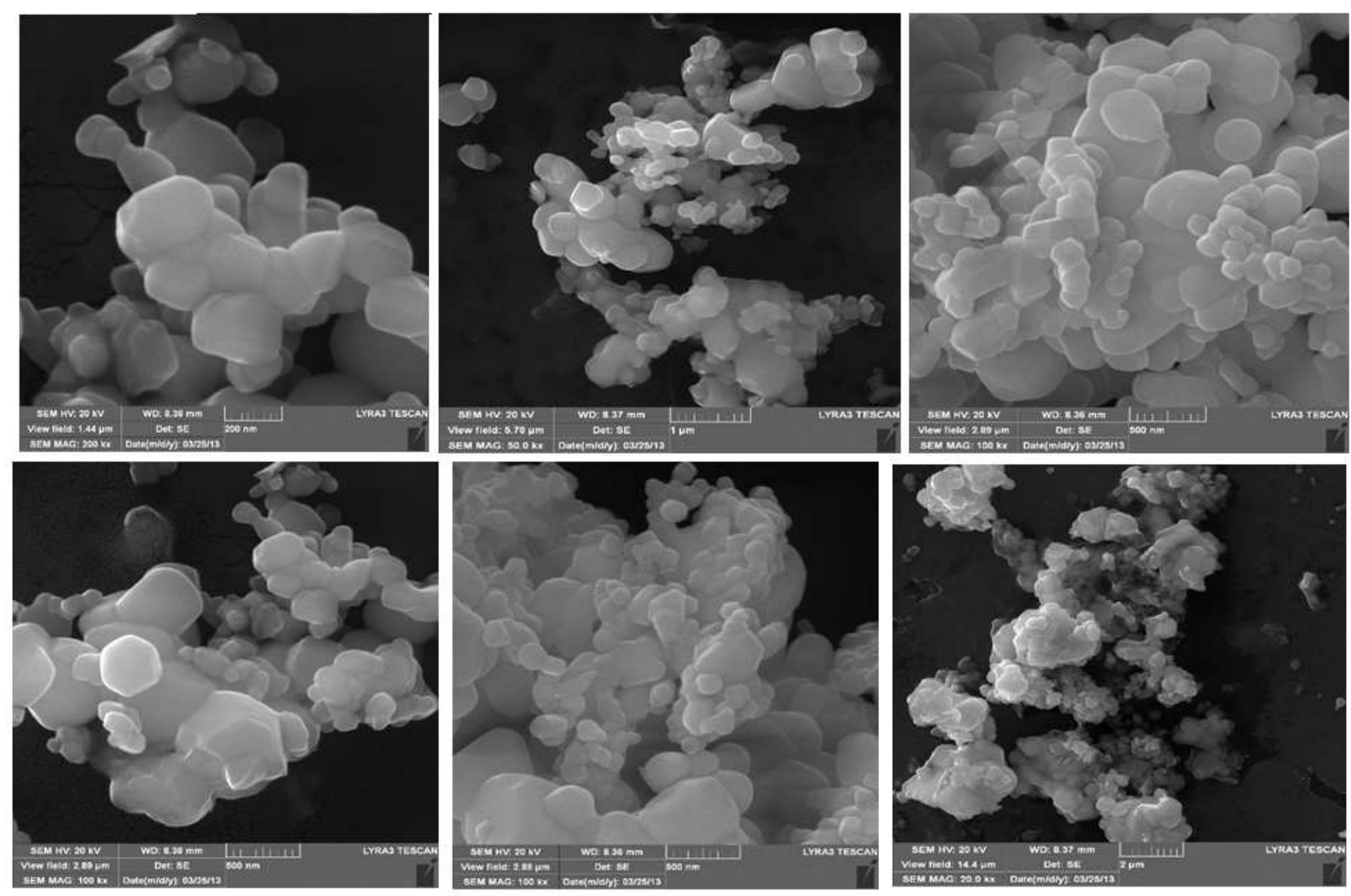

Figure 2

FESEM images of ZnO NPs, shape and size distribution of particles in the nanopowder. 

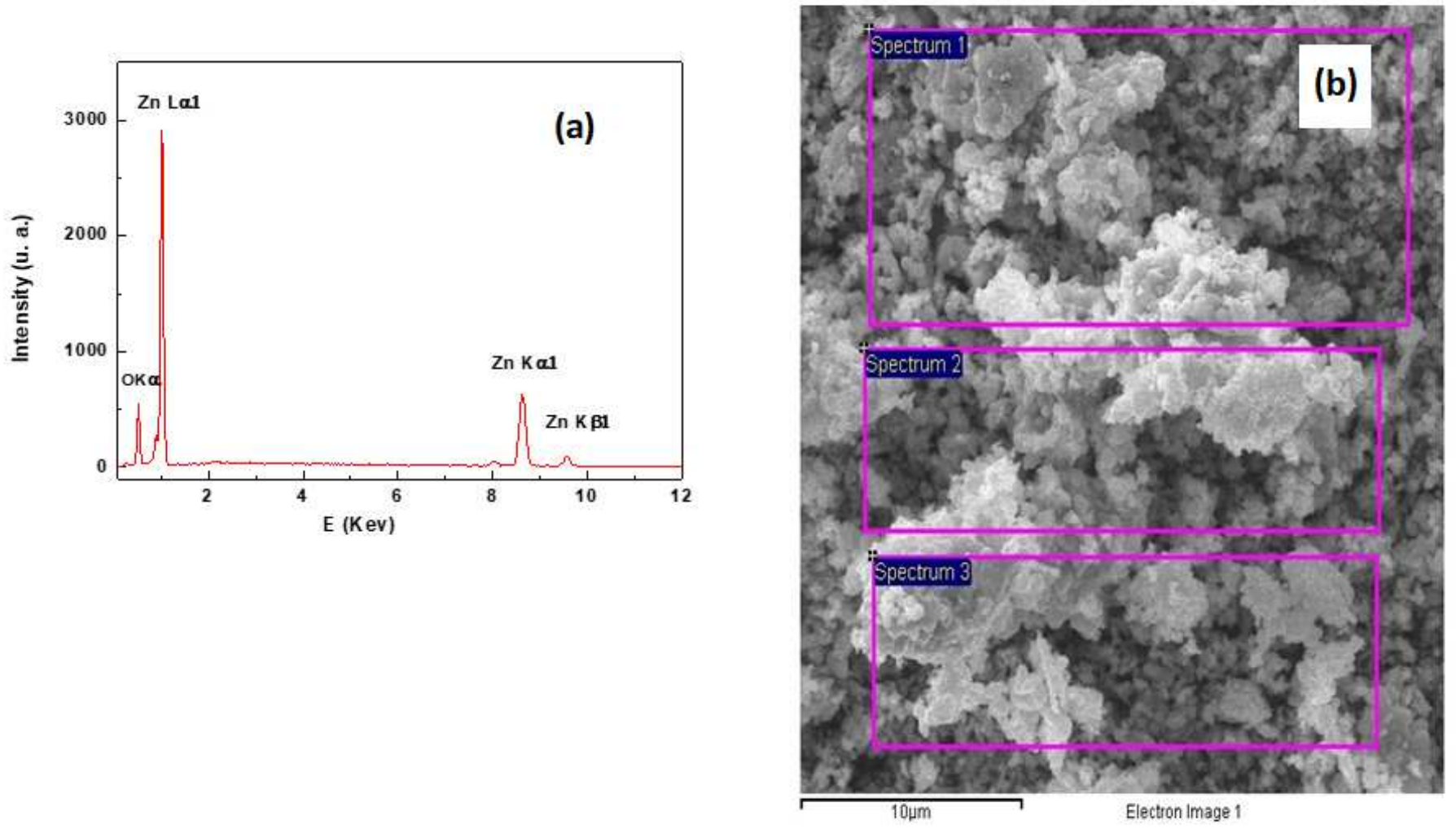

\section{Figure 3}

EDX results of ZnO nanopowder, (A) EXD spectrum and (B) SEM image of the analyzed regions of the nanopowder.
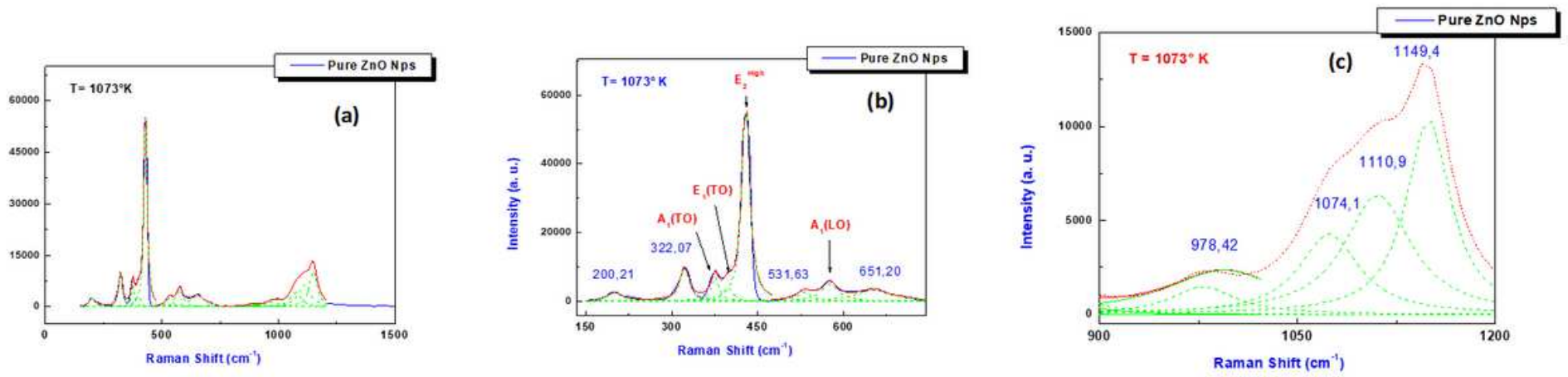

Figure 4

Raman spectra of $\mathrm{ZnO}$ nanopowder (the Raman phonon modes are fitted with Lorentzien function). 


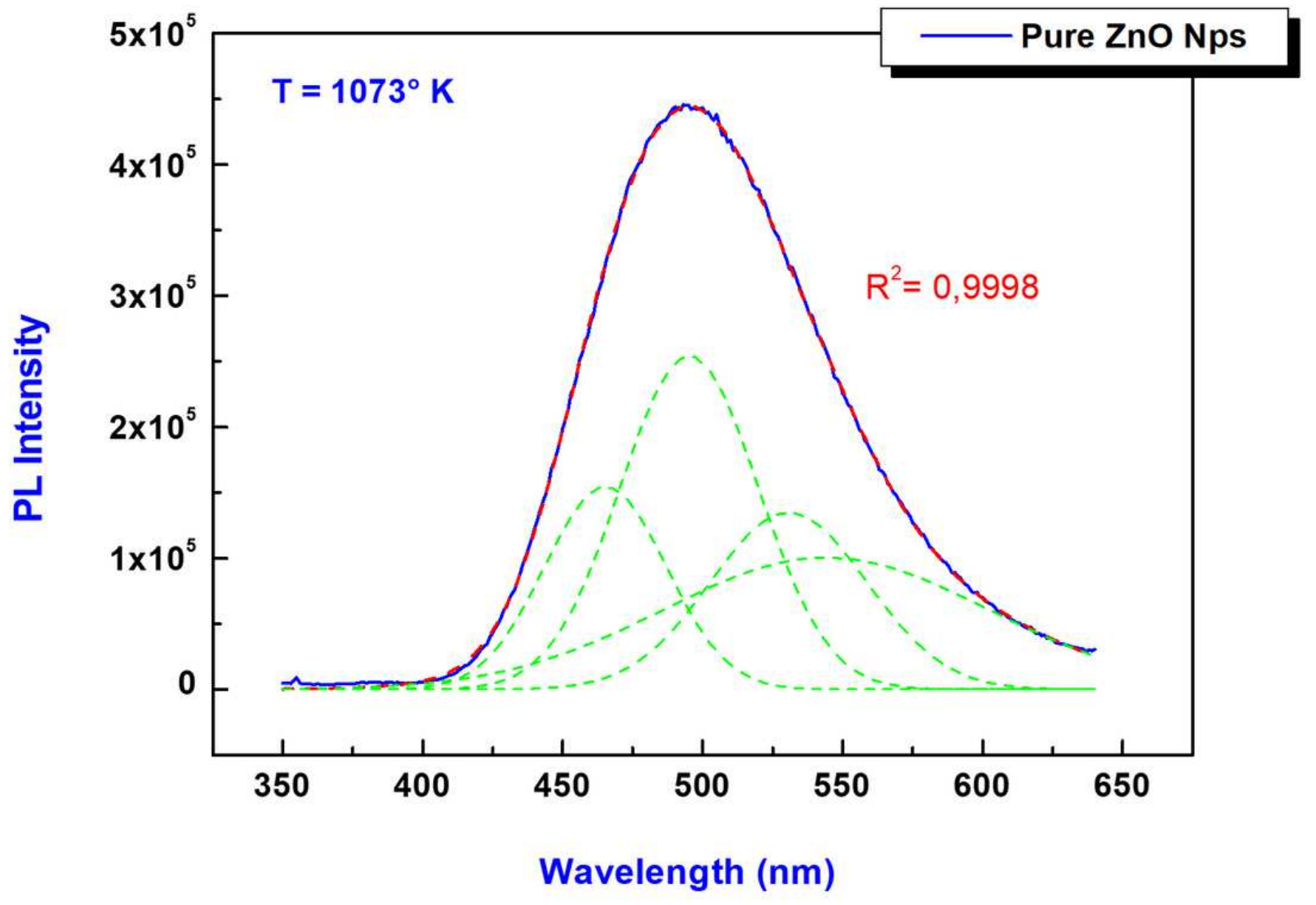

Figure 5

Room temperature photoluminescence spectra of $\mathrm{ZnO}$ nanopowder exited at $\mathbf{3 2 5} \mathrm{nm}$. (The emission spectra are analyzed by fitting with multiple Gaussian curves). 

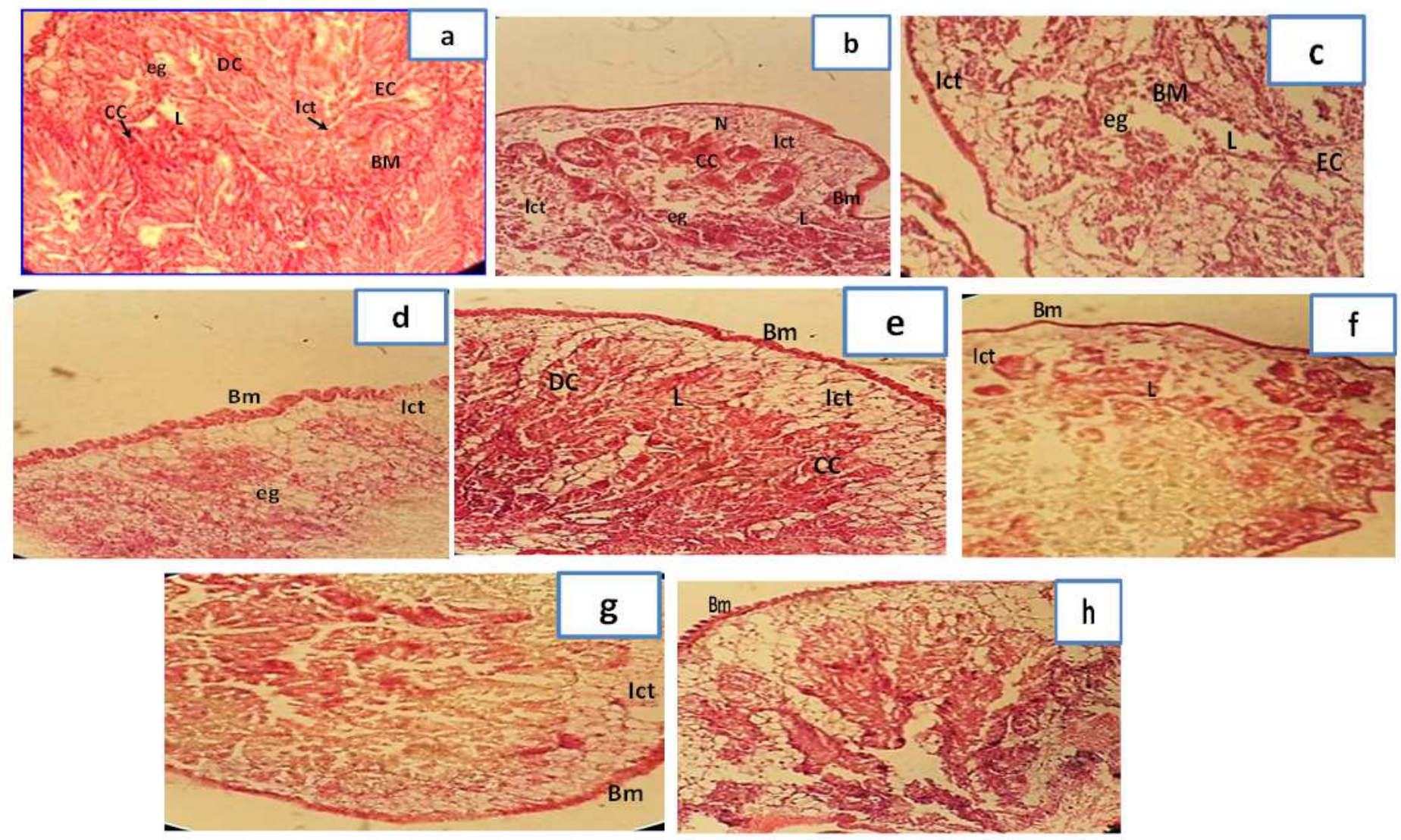

\section{Figure 6}

Histological sections of the hepatopancreas of snails $H$. aspersa in control and treated groups (after 4 weeks of treatment with ZnO NPs). L, Digestive tubule lumen; DC, digestive cells; CC, calcium cells; EC, excretory cells; Ict, intertubular connective tissue; eg, excretory granules; BM, basement membrane; Bm, border in encounter of microvilli; Acb, apical cell border. (a) Control snails. (b) snails treated with $100 \mu \mathrm{g} / \mathrm{g}$ of ZnO NPs. (c) snails treated with $500 \mu \mathrm{g} / \mathrm{g}$ of ZnO NPs. (d) snails treated with $1000 \mu \mathrm{g} / \mathrm{g}$ of ZnO NPs. (e) snails treated with $1500 \mu \mathrm{g} / \mathrm{g}$ of ZnO NPs. (f) snails treated with $2000 \mu \mathrm{g} / \mathrm{g}$ of ZnO NPs. (g) snails treated with $5000 \mu \mathrm{g} / \mathrm{g}$ of ZnO NPs. (h) snails treated with $10000 \mu \mathrm{g} / \mathrm{g}$ of ZnO NPs.

\section{Supplementary Files}

This is a list of supplementary files associated with this preprint. Click to download.

- Table1.docx

- Table2.docx

- Table3.docx

- Table4.docx 